\title{
INCIDENCE OF POSTERIOR CAPSULAR OPACIFICATION AFTER UNEVENTFUL CATARACT SURGERY IN PATIENTS ON HEMODIALYSIS
}

\author{
Yildiz Aydin, Comez Taskiran Arzu \\ ${ }^{1}$ Canakkale Onsekiz Mart University, Faculty of Medicine, Department of Ophthalmology, Turkey
}

Primljen/Received 22. 01. 2019. god.

Prihvaćen/Accepted 08. 06. 2019. god.

\begin{abstract}
Purpose: To evaluate the incidence of posterior capsular opacification after cataract surgery in patients on hemodialysis. Patients and Methods: Fifty patients on hemodialysis undergoing cataract surgery and 50 patients undergoing cataract surgery in a similar age group without any systemic disease were compared retrospectively. All patients underwent uneventful phacoemulsification surgery. Hydrophilic monoblock, sharp-edged acrylic intraocular lens (Spectrafold $^{\mathrm{TM}}$, Gujarat, India) was used. A complete ophthalmological examination was performed on the patients who were evaluated at the postoperative 12th month follow-up examination. Posterior capsular opacification was evaluated by the retroillumination method. According to the reflection from retroillumination, cases with posterior capsular opacification were divided into three groups as mild, moderate and severe.

Results: Age groups and male to female ratios were similar. Mean best corrected visual acuity (BCVA) was 0.23 in the hemodialysis group and 0.22 in the control group, preoperatively. At the end of the first year, the mean BCVA was 0.88 in the hemodialysis group and 0.94 in the control group. In the hemodialysis group, the percentage of posterior capsular opacification was $60 \%$ and was $14 \%$ in the control group; this difference was statistically significant $(p<0.05)$. While the capsular opacity was mild in all 7 patients in the control group, itwas mild in 19 patients, moderate in 8 and severe in 3 patients in the hemodialysis group. Conclusion: The incidence of posterior capsular opacification after uneventful cataract surgery is found to be higher in patients on hemodialysis than in the normal population.
\end{abstract}

Key words: Hemodialysis, cataract, phacoemulsification, posterior capsular opacity, PCO.

\section{INTRODUCTION}

Cataract is one of the most common causes of loss of vision in the elderly population. Currently, the met- hod used for surgery is the phacoemulsification surgery. With this method, lens material is emulsified and aartificial intraocular lens (IOL) is inserted in the bag formed by lens capsule.

The most common complication encountered after uneventful phacoemulsification surgery is proliferation of the remaining lens epithelial cells within the capsule transforming to a fibrotic process leading to posterior capsule opacification (PCO). The incidence of $\mathrm{PCO}$ is between 2 to $5 \%$ in the literature, though rates up to $50 \%$ are also reported (1-5). Yag laser capsulotomy is performed as treatment.

The causes of posterior capsular opacification may be listed as factors linked to the surgery, the type and design of the IOL inserted and the factors related to the patient. During surgery, if lens cells are not sufficiently cleaned from the posterior capsule, PCO may easily develop. In order to prevent PCO, it is recommended that an extra cleaning attempt like polishing should be applied routinely to the posterior capsule (3).

The type, material and design of IOL also affect PCO development. The PCO rates were common with IOLs made of polymethyl methacrylate (PMMA), but there has been a large reduction in PCO incidence with acrylic IOLswhich are recently more commonly used.Studies in recent years have shown that use of sharp-edged acrylic IOL reduces the development incidence of PCO $(2,4,5)$.

The patient-linked factors are young patient age,patient with systemic disease such as diabetes,, patients with ocular disease such as uveitis and medication use such as corticosteroids (6). PCO is commonly observed in those with pseudoexfoliation, uveitis or traumatic cataracts and patients with myotonic dystrophy (7).

The correlation between PCO with systemic diseases has not been fully researched, apart from diabetes. Cataracts are commonly observed with medications 
used for chronic renal failure and with the effect of hemodialysis (8). This study was planned as no study related to the development of opacification of the posterior capsule after cataract surgery in hemodialysis patients was found in the literature.

\section{PATIENTS AND METHODS}

This study was completed by retrospectively screening of files of hemodialysis patients who underwent uneventful phacoemulsification surgery from 2015 to 2017. Informed consent was obtained from all patients and the study abided by the Declaration of Helsinki criteria. Ethical approval was taken from Canakkale Onsekiz Mart University Ethical Committe. Fifty patients undergoing hemodialysis with cataract surgery were compared with 50 healthy patients without systemic disease in a similar age group.

Inclusion criteria for the study are as follows: adult patients aged 50 years and older, those with no systemic disease, those under hemodialysis treatment and those attending 1-year follow-up. Patients with uveitic cataracts, with corneal pathology or with retinal disease were not included in the study. Visual acuity was assessed with Snellen test.

For the surgical method, after $2.8 \mathrm{~mm}$ corneal incision intracameral lidocain $\mathrm{Hcl}$ and viscoelastic are administered, 5-5.5 mm capsulorhexis was performed. All surgeries were performed by one surgeon. (AY) Lens material was aspirated with a phaco instrument (Infiniti Vision system, Alcon Laboratories, Inc., Fort Worth, TX, USA). A 0.9 mm Kelman Micro Tipphaco tip with $45^{\circ}$ was used in all cases. Cortex material was cleaned with irrigation aspiration.Hydrophilic acrylic IOL (Spectrafold ${ }^{\mathrm{TM}}$, Gujarat, India) was used. Intraocular lens properties were refractive index 1.465, water content 26\%, monoblock, sharp-edges, non-ionic structure with material stated to reduce PCO rates. All patients were prescribed with topical corticosteroid (Maxidex, Alcon Laboratories) and antibiotic (Viga- mox, Alcon Laboratories) drops five times daily for three weeks.

Patients attending the 1st year follow-up examination had full ophthalmologic examination performed and PCO development was assessed with the retroillumination method by biomicroscopy. According to reflections from retroillumination, PCO was classified in three groups as mild, moderate and severe. After pupillary dilatation, peripheral capsular opacification was accepted as mild, PCO extending to paracentral area as moderate, and PCO including center of the lens is accepted as severe.

Statistical analyses were evaluated withStatistical Package for the Social Sciences (SPSS) program. Categorical variables were given as mean \pm standard deviations and with percentages. For the comparison of the groups independentsamples t-test was used. Statistical significance was accepted as a $\mathrm{p}$ value of $<0.05$.

\section{RESULTS}

Mean age in the hemodialysis group was 65.2 years, while it was 66.7 years in the control groups ( $p>$ 0.05 ). The female/male ratio in the hemodialysis group was $24 / 26$, while it was $21 / 29$ in the control group.

Average phacoemulsification time and surgery duration were $8.2 \%$ and 13.4 minutes in hemodialysis group, respectively. Phaco-power were used as with a range of 30 to 40 according to the grade of cataract. Average phaco-time and surgery duration were $8.1 \%$ and 13.1 minutes in control group. There was no statistical significance in terms of phaco time and surgery duration $(\mathrm{p}>0.05)$.

Preoperative mean best corrected visual acuity was 0.23 in the hemodialysis group, while it was 0.22 in the control group. At the end of the first year, mean visual acuity was 0.88 in the hemodialysis group and 0.94 in the control group. Details related to upper and lower values are given in Table 1.

The most noteworthy finding was the PCO incidence in the hemodialysis group. Rates of $60 \%$ were

Table 1. Demographic and Visual Acuity findings

\begin{tabular}{|l|c|c|c|}
\hline & Hemodialysis Group & Control Group & P value \\
\hline Age & $\begin{array}{c}65.2 \pm 3.4 \\
\text { Min-max: } 58-73\end{array}$ & $\begin{array}{c}66.7 \\
\text { Min-max: } 61-77\end{array}$ & 0.447 \\
\hline Gender (Female/Male) & $24 / 26$ & $21 / 29$ & 0.549 \\
\hline $\begin{array}{l}\text { Mean Preoperative best corrected visual acuity } \\
\text { (Snellen Chart) }\end{array}$ & $\begin{array}{c}0.23 \\
\text { Min-max: } 0.1-0.4\end{array}$ & $\begin{array}{c}0.22 \\
\text { Min-max: } 0.1-0.4\end{array}$ & 0.689 \\
\hline $\begin{array}{l}\text { Mean Postoperative 3rd month best corrected } \\
\text { visual acuity (Snellen Chart) }\end{array}$ & 0.97 & 0.96 & 0.041 \\
\hline $\begin{array}{l}\text { Mean Postoperative 1st year best corrected } \\
\text { visual acuity (Snellen Chart) }\end{array}$ & 0.88 & 0.94 & 0.000 \\
\hline Posterior Capsular Opacification Rate & $60 \%$ & $14 \%$ & 0.000 \\
\hline
\end{tabular}


Table 2. Ocular characteristics

\begin{tabular}{|l|l|l|}
\hline & Hemodialysis Group & Control group \\
\hline \multirow{4}{*}{ Types of Cataract } & Cortical - 13 & Cortical - 10 \\
& Nuclear - 12 & Nuclear - 14 \\
& Posterior subcapsular - 17 & Posterior subcapsular-12 \\
& Mature - 8 & Mature -14 \\
\hline
\end{tabular}

observed in the hemodialysis group while a rate of $14 \%$ is seen in the control group and this difference was statistically significant $(\mathrm{p}<0.05)$. All 7 patients with PCO in the control group had mild degree of capsular opacity, while in the hemodialysis group 19 patients had mild, 8 patients had moderate and 3 patients had severe degrees of opacity identified.

Ocular characteristics were listed in Table 2.

\section{DISCUSSION}

There are variety of studies related to ocular findings in patients undergoing hemodialysis in the literature. One of these is the study by Minen et al. about intraocular pressure, corneal thickness, eye dryness and contrast sensitivity in 42 hemodialysis patients. While there was no difference in terms of intraocular pressure and corneal thickness compared to the control group, the hemodialysis group had lower Schirmer test results and lower contrast sensitivity degrees (9). A study of 30 patients by Demir et al. identified cataract in 3 patients, while 22 patients had corneal-conjunctival calcification (10).

One of the eye findings due to high urea levels and calcification in hemodialysis patients, is cataracts withrates up to $58 \%(11,12,13)$. A study of patients with chronic renal failure reported a strong correlation between the severity of renal disorder and cataract development risk. (14).

Dursun et al. performed extracapsular cataract extraction surgery with small incision and suture methods for 82 chronic renal failure patients with cataracts in a two-year period. Of the patients, $14.6 \%$ (12 patients) encountered a variety of postoperative problems. In 10 of these 12 patients, suture infection was observed (15).

With cataract surgery with the narrow incision entry method and phacoemulsification surgery, almost no sutures are used and more successful results are obtained. A study by Chen et al. reported 1.0 level of visual acuity was reached in $52 \%$ of patients in the postoperative period (16). In our study, $72 \%$ of patients had 1.0 level of visual acuity identified in the first postoperative month.

Though there are studies related to hemodialysis and cataracts in the literature, there was no study encountered about the incidence of posterior capsular opaci- fication in hemodialysis patients. This topic was studied in our research and high rates of $\mathrm{PCO}$ incidence were observed. The reasons for this may be listed as lens epithelial cells remaining during surgery preparing the way for formation of posterior capsule opacification. These cells are present in nearly all patients at low amounts, but are known to remain at the lens equator.

During cataract surgery, the anterior capsule of the lens is opened and there is direct contact between anterior chamber fluid and lens contents. As hemodialysis patients have more accumulation of toxic metabolites compared to normal individuals, the contact rate of urea to the lens increases and PCO may be observed more often due to increased oxidative stress $(10,17)$. Another probable explanation is that as the posterior subcapsular region is sensitive to oxidative stress, this may also be valid for the posterior capsule (18).

Additionally, abnormalities of remaining lens epithelial cells due to acidosis (19) or disrupted lens epithelial cell metabolism linked to vitamin D deficiency resulting in formation of calcium deposits in the posterior capsule, may be the reason for the high incidence of PCO observed (20).

In conclusion, hemodialysis patients with uneventful cataract surgery appear to have higher incidence of posterior capsule opacification compared to the normal population.
Abbreviations
PCO - posterior capsular opacification
IOL — intraocular lens
PMMA - polymethyl methacrylate
SPSS - Statistical Package for the Social Sciences

Acknowledgment: None

Conflict of Interests: The authors declare that there are no conflicts of interest related to this article.

Funding: This research did not receive any specific grant from funding agencies in the public, commercial, or not-for-profit sectors.

\section{Licensing}

This work is licensed under a Creative Commons Attribution 4.0 International (CC BY 4.0) License. 


\title{
Sažetak
}

\section{UČESTALOST ZAMUĆENJAZADNJE KAPSULE SOČIVA NAKON RUTINSKE OPERACIJE KATARAKTE KOD PACIJENATA NA HEMODIJALIZI}

\author{
Yildiz Aydin, Comez Taskiran Arzu \\ ${ }^{1}$ Canakkale Onsekiz Mart University, Faculty of Medicine, Department of Ophthalmology, Turkey
}

Cilj: Cilj ovog rada bio je da se proceni incidenca zamućenja zadnje kapsule sočiva nakon operacije katarakte kod pacijenata na hemodijalizi.

Pacijenti i metode: 50 pacijenata na hemodijalizi koji su bili podvrgnuti operaciji katarakte i 50 pacijenata slične starosne dobi i bez sistemskih oboljenja koji su bili podvrgnuti operaciji katarakte su upoređivani retrospektivno. Svi pacijenti su bili podvrgnuti rutinskoj fakoemulzifikaciji. Korišćena su hidrofilna monoblok, intraokularna sočiva oštrih ivica (Spectrafold ${ }^{\mathrm{TM}}$, Gujarat, Indija). Kompletan oftalmološki pregled izveden je kod svih pacijenata 12 og postoperativnog meseca na redovnom kontrolnom pregledu. Zamućenja zadnje kapsule sočiva ispitivano je metodom retroiluminacije. Prema refleksiji dobijenoj retroiluminacijom, slučajevi sa zamućenjem zadnje kapsule sočiva bili su podeljeni u tri grupe: kao blago, umereno i ozbiljno zamućenje.

\section{REFERENCES}

1. Wilhelmus KR, Emery JM. Posterior capsule opacification following phacoemulsification. Ophthalmic Surg. 1980; 11(4): 264-7.

2. Wu S, Tong N, Pan L, Jiang X, Li Y, Guo M, et al.. Retrospective analyses of potential risk factors for posterior capsule opacification after cataract surgery. J Ophthalmol. 2018; 2018:9089285. doi: 10.1155/2018/9089285.

3. Awasthi N, Guo S, Wagner BJ. Posterior capsular opacification: a problem reduced but not yet eradicated. Arch. Ophthalmol. 2009; 127(4): 555-62.

4. Çomez AT, Ozkurt YB, Karadag O, Dogan OK. The effect of intraocular lens material on posterior capsular opacification. Kartal Egitim ve Arastirma Hastanesi Tip Dergisi. 2006; 17(1): 17-21.

5. Zhao Y, Yang K, Li J, Huang Y, Zhu S. Comparison of hydrophobic and hydrophilic intraocular lens in preventing posterior capsule opacification after cataract surgery: An updated meta-analysis. Medicine (Baltimore). 2017; 96(44): e8301. doi:10.1097/MD. 0000000000008301.

6. Iliescu IM, Constantin MA, Cozma C, Moraru OM, Moraru CM. Posterior capsule opacification and Nd-YAG rates evaluation in a large series of pseudophakic cases. Rom J Ophthalmol. 2017; 61(4): 267-74.

7. Langwiñska-Woœko E, Broniek-Kowalik K, Szulborski K. The impact of capsulorhexis diameter, localization and shape on posterior capsule opacification. Med Sci Monit. 2011; 17(10): CR577-82.
Rezultati: Odnosi po pitanju godina starosti i pola unutar grupa bili su slični. Srednja najbolje korigovana vidna oštrina (BCVA) bila je 0,23 u grupi pacijenata na hemodijalizi i 0,22 u kontrolnoj grupi, preoperativno. $\mathrm{Na}$ kraju prve godine, srednja vrednost BCVA bila je 0,88 u grupi na hemodijalizi i 0,94 u kontrolnoj grupi. $\mathrm{U}$ grupi na hemodijalizi procenat zamućenja kapsule bio je $60 \%$, dok je u kontrolnoj grupi iznosio $14 \%$. Ova razlika je bila statistički značajna $(\mathrm{p}<0,05)$. Dok je kapsularno zamućenje bilo blago kod svih 7 pacijenata u kontrolnoj grupi, bilo je blago kod 19 pacijenata, umereno kod 8 i teško kod 3 pacijenta u grupi koji su bili na hemodijalizi.

Zaključak: Pokazalo se da je učestalost zamućenja zadnje kapsule sočiva nakon rutinske operacije katarakte veća kod pacijenata na hemodijalizi nego u normalnoj populaciji.

Ključne reči: hemodijaliza, katarakta, fakoemulzifikacija, zamućenje zadnje kapsule sočiva, PCO.

8. Rim TH, Yoon CY, Park HW, Chung EJ: Association between starting hemodialysis for end-stage renal disease and incident cataract surgery: a 12-year nationwide cohort study. Invest Ophthalmol Vis Sci. 2016; 57(3): 1112-9.

9. Minen M, Ar2c2 MK, Erdogan H, Topalkara A, Toker I, Gültekin F. ŠOphtalmologic findings in hemodialysis patients ${ }^{1}$. Turk J Ophthalmol 2001; 31: 352-60.

10. Demir MN, Kocaoglan H, Akay H, Duranay M, Duman S. [Ophtalmologic findings in chronic renal disease]. Turk J Ophthalmol 2006; 36(2): 150-5.

11. Stibor V, Lachmanová J, Tomásek R. Changes in the lens and cataract surgery in dialyzed patients. Cesk Oftalmol. 1989; 45(4): 253-60.

12. Vrabec R, Vatavuk Z, Pavlovic D, Sesar A, Cala S, Mandic K, et al. Ocular findings in patients with chronic renal failure undergoing hemodialysis. Coll Antropol. 2005; 29(suppl 1): $95-8$.

13. Albert K, Sennesael J, Haentjens P. Incidence and risk factors for posttransplant subcapsular cataract: a long-term retrospective cohort study. Transplant Proc. 2011; 43(9): 3465-9.

14. Liu YT, Hung TY, Lee YK, Huang MY, Hsu CY, Su YC. Association between chronic kidney disease and risk of cataract: A nationwide retrospective cohort study. Am J Nephrol. 2017; 45(6): 524-31.

15. Dursun D, Akova YA, Akman A, Oto S, Aydin P. Complications of extracapsular cataract surgery in chronic renal failure patients. Eye (Lond). 2000; 14 (2): 176-9.

16. Chen Y, Cai J, Liu H. Phacoemulsification and intraocular lens implantation in patients with chronic renal failure and cataract. Zhonghua Yan KeZaZhi. 2001; 37(5): 332-4. 
17. Delcourt C, Carriere I, Delage M, Descomps B, Cristol JP, Papoz L. Associations of cataract with antioxidant enzymes and other risk factors: the French Age-Related Eye Diseases (POLA) Prospective Study. Ophthalmology. 2003; 110(12): 2318-26.

18. Hodge WG, Whitcher JP, Satariano W. Risk factors for age related cataracts. Epidemiol Rev. 1995; 17(2): 336-46.
19. Metcalfe W, Khan IH, Prescott GJ, Simpson K, Macleod AM; Scottish Renal Registry. End-stage renal disease in Scotland: outcomes and standards of care. Kidney Int. 2003; 64(5): 1808-16.

20. Huynh SC, Kifley A, Strippoli GF, Mitchell P. Is renal impairment a predictor of the incidence of cataract or cataract surgery: findings from a population-based study. Ophthalmology. 2005; 112(2): 293-300.

\section{Correspondence to/Autor za korespondenciju}

\section{Dr. Aydin YILDIZ}

Address: Canakkale Onsekiz Mart University, Faculty of Medicine, Department of Ophthalmology Barbaros Cad, 17100, Canakkale -TURKEY

Telephone: +905335594850

Fax: 02126954829

E-mail: aydinyildiz@comu.edu.tr 